\title{
The Growth Response of Clarias gariepinus Hatchlings to Different Dry Feeds
}

\author{
Ikililu Abdulraheem ${ }^{1}$, S. O. Otubusin ${ }^{1}$, O. T. Agbebi ${ }^{1}$, O. Olowofeso ${ }^{2}$, Wilfred O. Alegbeleye ${ }^{1}$, W. O. Abdul ${ }^{1}$, \\ Khadijat Adeyemi ${ }^{2}$, Samuel S. Ashley-Dejo ${ }^{1} \&$ Bamidele Nathaniel $^{1}$ \\ ${ }^{1}$ Department of Aquaculture and Fisheries Management, Federal University of Agriculture, Abeokuta, Nigeria \\ ${ }^{2}$ Department of Animal breeding and Genetics, Federal University of Agriculture, Abeokuta, Nigeria \\ Correspondence: Ikililu Abdulraheem, Department of Aquaculture and Fisheries Management, Federal \\ University of Agriculture, Abeokuta, Nigeria. Tel: 234-803-564-3663. E-mail: a.ikililu@yahoo.com
}

Received: May 21, 2012 Accepted: June 6, 2012 Online Published: August 24, 2012

doi:10.5539/jas.v4n10p75 URL: http://dx.doi.org/10.5539/jas.v4n10p75

\begin{abstract}
The hatchery facilities of a reputable fish farm in Abeokuta were used to carry out studies on the effects of different diets on the survival of African catfish Clarias gariepinus hatchlings. The larvae (1.8mg each) were distributed into the twelve feeding experiment apartments $(1.7 \mathrm{~m} \times 0.7 \mathrm{~m} \times 0.5 \mathrm{~m}$ each $)$ at 1,500 lavae/apartment. On the fourth day, feeding commenced with the experimental diets. The diets were fish meal (Danish) of $72 \%$ Crude Protein; baker's yeast (VAHINE); compounded feed (50\% Crude Protein) and hen egg yolk. Each treatment was replicated thrice and feed fed to the larvae at $30 \%$ body weight twice daily for 30 days. All the experimental diets had no significant effects on the growth of the larvae to fingerling at $\mathrm{P}>0.05$. The mean fingerlings final weight $(\mathrm{mg})$ was $1523.2 \pm 295,1700.8 \pm 686,367.9 \pm 118$ and $1675.9 \pm 1167$ for fish meal, yeast, compounded feed and hen egg yolk respectively. The specific and relative growth rates of the larvae under all the treatments were also not significant $(\mathrm{P}>0.05)$. Considering the growth parameters, the best performance was observed in fish fed diet 2 (yeast), closely followed by diet 4 (hen egg yolk), then diet 1 (fish meal) and least in fish fed diet 3 (compounded feed). The low survival rate observed in all the diets, Compounded feed $(10 \%)>$ hen egg yolk $(4.1 \%)>$ Fish meal $(3.5 \%)>$ yeast $(1.7 \%)$ could be attributed to the lack of sorting exercise carried out in the experiment.
\end{abstract}

Keywords: growth response, catfish, fingerlings and dry feeds

\section{Introduction}

The expansion and intensification of aquaculture production has been recommended towards ensuring increase in food fish production in order to meet up with the global demand since capture fisheries have continued to be on the decline over decades (Delgado et al., 2003). The need to intensify the culture of the fish, so as to meet the ever increasing demand for fish has made it essential to develop suitable diets either in supplementary forms for ponds or as complete feed in tanks (Olukunle, 2006). For the purpose of nutritional and economic benefits, previous researchers have made attempts at increasing the use of nonconventional plant and animal materials to replace conventional feed ingredients like maize and fish meal in fish feed ration (Falaye, 1988; Fagbenro, 1992; Olatunde, 1996; Baruah et al., 2003; Eyo, 2004).

Proper growth of fish depends largely on good nutrition and this is more pronounced with fish in enclosure as they require adequate nutrition (Omoruwou \& Edema, 2011). This poses a number of challenges to the fish farmer. Firstly, feed ingredients notably fish meal presently in use is expensive (Akinwande et al., 2002; Dada \& Akinwande, 2005).

Falaye (1992) estimated the feeding cost to be about $60 \%$ of the recurrent cost of fish farming, minimizing the profit margin of fish farmers and negating the economic viability of the fish industry (Omoruwou \& Edema, 2011). Feed is generally the largest expenditure in semi-intensive and intensive fish culture operations, and protein is the most expensive component of feeds (Zhou et al., 2010). In fish farming, nutrition is critical because fish feed represents $40-50 \%$ of the total production costs.

The objective of this study is to monitor the growth response and the survival of the catfish larvae fed different dry dietary treatments (fish meal, yeast, compounded diet and hen egg yolk). 


\section{Materials and Methods}

\subsection{Experimental Site}

The hatchery facilities of a private fish farm known as Aqua Consult Ltd situated in Abeokuta was used for the study. Four concrete nursery tanks $(2.8 \mathrm{~m} \times 1.7 \mathrm{~m} \times 1 \mathrm{~m}$ each $)$ were situated outside with PVC water inlet and outlet devices, water supply was from borehole with an overhead tank for water storage.

Three of the outdoor nursery tanks (ONT) labeled ONT1, ONT2 and ONT3 were used for the study. For the purpose of this study, each of the tanks was partitioned into 4 compartments with a netted $(0.5 \mathrm{~mm}$ mesh size $)$ rectangular wooden framed $(\mathrm{L} \times \mathrm{B}: 1.7 \mathrm{~m} \times 0.7 \mathrm{~m})$ to prevent larvae from escaping from one compartments to another. The sides and the bottom of each wooden frame were further stuffed with sacs to prevent escape of fish and drift of experimental feed to adjacent compartment. The twelve compartments coded as APT1, APT2, APT3, APT4, APT5, APT6, APT7, APT8, APT9, APT10, APT11 and APT12 with perimeter and surface area of $4.74 \mathrm{~m}$ and $1.16 \mathrm{~m}$ respectively were impounded with water from the overhead tank to depth of $0.45 \mathrm{~m}$. The three nursery tanks were fertilized with sieved dried poultry manure (1.5kg tank) and left for 2 weeks to introduce organisms suitable as live starter food and serve as a constant factor for all the four (4) treatments (fish meal (T1), yeast (T2), compounded feed (T3) and hen egg yolk (T4)). Prior to stocking the fertilized water was collected and tested for its water quality parameters, such as $\mathrm{pH}, \mathrm{DO}, \mathrm{NH}_{4}, \mathrm{NO}_{3}$ and temperature. Each apartment was stocked with four days old 1,500 pieces of larvae of average weight of $1.8 \mathrm{mg}$. The compounded feed (T3) and fish meal (T1) were sieved using $2 \mathrm{~mm}$ mesh size sieve and the hen egg yolk (T4) was prepared into a paste using sterilized water and yeast (T2) was fed directly because of it was already in micro size suitable for the fish larvae to consume. Feeding commenced immediately with the experimental diets and the fish were feed to satiation. Sampling exercise was carried out weekly by weighing the fish using a sensitive weighing balance.

The outdoor nursery tanks were covered with screened rectangular wooden frame to protect the stock from dragon fly and other predators. A palm frond shed was created to shade out the nursery unit from direct sunlight thereby creating a cooling effect on the nursery tanks. A water flow-through system was allowed to run at 1 litre/min onto the nursery unit throughout the period of study of one month. Water quality parameters were carried out weekly to determine $\mathrm{pH}, \mathrm{DO}, \mathrm{NH}_{4}$ and $\mathrm{NO}_{3}$.

\subsection{Experimental Diets}

The dry feeds for the study were egg-yolk, fish meal (Danish, 72\% crude protein), baker's yeast (VAHINE) and formulated feed ( $50 \%$ crude protein) otherwise known as treatment I, II, III and IV respectively. Each treatment was replicated twice and fed to the larvae twice daily (morning and evening) for 30 days at $30 \%$ body weight.

Eggs were hard boiled daily and yolk removed, weighed and each daily ration was fed to all the replicates.

The fish meal used was Danish fish meal, it was sieved with $0.5 \mathrm{~mm}$ sieve. Baker's yeast (VAHINE) tagged as the third treatment was also feed to the larvae. Lastly was the formulated diet of $50 \%$ crude protein.

\subsection{Growth Parameters}

The growth parameters were calculated as follows:

a) \% Survival $=\frac{\text { No of fry at the end of study }}{\text { No of larvae at the beginning of study }} \times 100$

b) Specific Growth Rate \%/day $($ SGR $)=\frac{\text { Log final weight }- \text { Log initial } w e i g h t}{\text { Time }(\text { days })} \times 100$

c) Relative Growth Rate RGR (\%) $=\frac{w_{f}-w_{i}}{w_{i}} \times 100$

Where:

$\mathrm{W}_{\mathrm{i}}$ - Initial weight (mg) of fish i.e. at the beginning of the experiment

$\mathrm{W}_{\mathrm{f}}$ - Final weight of fish i.e. at the end of the experiment

d) Feed Conversion Ratio $=\frac{\text { Feed Given }(\mathrm{mg})}{(\text { Final }- \text { Initial weight })}$ 


\title{
2.4 Proximate Analysis of the Diets
}

Proximate analysis of the experimental diets was carried out acording to AOAC, (2000).

\section{Nitrogen Free Extract (NFE/\%)}

\author{
$\mathrm{NFE}=100-(\%$ Crude protein $+\%$ moisture $+\%$ crude fat $+\%$ Ash $+\%$ crude fibre $)$ \\ 2.5 Analysis of Data
}

Data collected were subjected to statistical analysis using one-way analysis of variance (ANOVA) test and the differences were tested for significance $(\mathrm{P}<0.05)$ using Duncan's Multiple Range Test (Duncan, 1955).

\section{Results}

\subsection{Percentage Survival of Hatchlings to Fingerlings}

The mean survival rate from hatchlings to fingerlings ranged from $1.7 \%-10 \%$. Treatment 3 (Compounded feed) had the highest mean survival rate of $10 \%$ followed by Treatments 4 (Hen egg yolk) and 1 (Fish meal) with $4.1 \%$ and $3.5 \%$ respectively. Treatment 2 (Yeast) had the least survival of $1.7 \%$ (Table 2).

Table 1. Composition of the formulated diet

\begin{tabular}{lc}
\hline Feed ingredients & \% Composition \\
\hline Maize & 8.67 \\
Soya beans meal & 36.53 \\
Groundnut cake & 18.26 \\
Fish meal & 36.53 \\
Vitamin premix* & 0.0625 \\
Methionine & 0.025 \\
Lysine & 0.025 \\
\hline Total & 100.102 \\
\hline
\end{tabular}

Source: Field Survey 2010.

*A premix used in poultry or fish feeds manufacture; contains thiamin, riboflavin, pyridoxine, pantothenic, nicotinic, biotin, folic acid, B12, choline, inositol, ascorbic acid, A, D3, E, K.

Table 2. Summary of the performance of Clarias gariepinus larvae fed with four diets for 4 weeks

\begin{tabular}{lllll}
\hline Parameters & Fish meal & Yeast & Compounded diet & Hen egg yolk \\
\hline Initial No Stocked & $1500 \pm 0.00^{\mathrm{a}}$ & $1500 \pm 0.00^{\mathrm{a}}$ & $1500 \pm 0.00^{\mathrm{a}}$ & $1500 \pm 0.00^{\mathrm{a}}$ \\
Initial Total Weight (mg) & $2775^{\mathrm{a}}$ & $2775^{\mathrm{a}}$ & $2760^{\mathrm{a}}$ & $2760^{\mathrm{a}}$ \\
Initial mean weight $(\mathrm{mg})$ & $1.85 \pm 0.02^{\mathrm{a}}$ & $1.85 \pm 0.09^{\mathrm{a}}$ & $1.84 \pm 0.02^{\mathrm{a}}$ & $1.84 \pm 0.02^{\mathrm{a}}$ \\
Final total weight $(\mathrm{mg})$ & $80729.6^{\mathrm{a}}$ & $44220.8^{\mathrm{b}}$ & $55552.9^{\mathrm{b}}$ & $103905.8^{\mathrm{c}}$ \\
Final mean weight $(\mathrm{mg})$ & $1532.2 \pm 295^{\mathrm{b}}$ & $1700.8 \pm 686^{\mathrm{a}}$ & $367.9 \pm 118^{\mathrm{c}}$ & $1675.9 \pm 1167^{\mathrm{a}}$ \\
Daily weight gain $(\mathrm{mg} /$ fish) & $50.7 \pm 9.87^{\mathrm{a}}$ & $56.6 \pm 22.8^{\mathrm{a}}$ & $9.5 \pm 3.97^{\mathrm{b}}$ & $55.7 \pm 38.9^{\mathrm{a}}$ \\
Relative weight gain \% & $81821.54 \pm 1539^{\mathrm{a}}$ & $92324.82 \pm 37757^{\mathrm{a}}$ & $19881.8 \pm 6475^{\mathrm{b}}$ & $90633.9 \pm 63031^{\mathrm{a}}$ \\
Specific growth rate & $9.65 \pm 0.33^{\mathrm{a}}$ & $9.66 \pm 0.56^{\mathrm{a}}$ & $7.52 \pm 0.43^{\mathrm{b}}$ & $9.07 \pm 1.0^{\mathrm{a}}$ \\
Feed conversion ratio & $3.08 \pm 0.35^{\mathrm{a}}$ & $2.54 \pm 0.42^{\mathrm{a}}$ & $2.21 \pm 0.78^{\mathrm{a}}$ & $1.02 \pm 0.01^{\mathrm{b}}$ \\
No of Survival & $53 \pm 6.66^{\mathrm{b}}$ & $26 \pm 4.70^{\mathrm{c}}$ & $151 \pm 62.5^{\mathrm{a}}$ & $62 \pm 32.3^{\mathrm{b}}$ \\
Percentage survival & $3.5 \pm 0.56^{\mathrm{b}}$ & $1.7 \pm 0.39^{\mathrm{c}}$ & $10 \pm 5.10^{\mathrm{a}}$ & $4.1 \pm 2.61^{\mathrm{b}}$ \\
\hline
\end{tabular}

Source: Field Survey 2010.

Means with same superscripts are not significantly different at $\mathrm{P}<0.05$.

\subsection{Mean Growth Performance from Hatchlings to Fingerlings}

Table 2 gives the summary of the initial and final average weight $(\mathrm{mg})$ of fish, the daily weight gain ( $\mathrm{mg} / \mathrm{fish} /$ day), relative weight gain, specific growth rate (SGR \%day) and \% survival of the hatchlings fed with the four dry diets.

The mean initial weight in all the treatments ranged from $1.84 \mathrm{mg}-1.85 \mathrm{mg}(1.84 \pm 0.0070)$ while the mean final weight was from $367.9 \mathrm{mg}-1700.8 \mathrm{mg}(1034.35 \pm 942.50)$. 
Treatment 2 (yeast) had the highest mean weight (mg) of $1700.8 \pm 686.70$ followed by treatment 4 (hen egg yolk) with $1675.9 \pm 1167.14$, treatment 1 (fish meal) had $1523.2 \pm 295.65$ and treatment 3 (Compounded feed) with the lowest of $367.9 \pm 118.85$.

The daily mean weight gain (mg/fish/day) of treatment 2 was the highest with $56.6 \pm 22.85$ followed by treatment 4 , 1,3 with $55.7 \pm 38.89,50.7 \pm 9.8692$ and $9.5 \pm 3.97$ respectively.

The relative weight gain was highest in Treatment 2 with $92324.82 \%$ followed by Treatment 4,1 and 3 with $90633.93 \%, 81821.54 \%$ and $19881.79 \%$ respectively.

The specific growth rate (\%day) SGR was highest in Treatments 1 and 2 with the same value of $9.65 \%$ followed by Treatments 4 and 3 with $9.07 \%$ and 7.52 respectively.

The feed conversion ratio (FCR) was represented in Table 2 with Treatment 4 (hen egg yolk) having the highest FCR value of 1.02 followed by Treatments 3, 2 and 1 with values of 2.21, 2.54 and 3.08 respectively.

Table 3 gives the proximate analysis of the experimental diets. The moisture content was in the range of $7 \%-10 \%$ for the four diets. The highest lipid content was recorded in Treatment 1 containing $10.0 \%$ and the least in Treatment 2 with $2.20 \%$ crude protein ranged from $2.79 \%-72.3 \%$ in Treatments 4 and 1 respectively.

\subsection{Physico-chemical Parameters}

The average temperature recorded in the tank during the experiment was $28{ }^{\circ} \mathrm{C} . \mathrm{p}^{\mathrm{H}}$ value 7.2 ; dissolved oxygen concentration $6.4 \mathrm{mg} ; \mathrm{NH}_{4} 0.5 \mathrm{mg} / \mathrm{l}$ and $0.05 \mathrm{mg} / \mathrm{l}$ for $\mathrm{NO}_{2}$ (Table 4).

Table 3. Proximate Composition of Experimental Diet

\begin{tabular}{rccccc} 
& & $\mathrm{T}_{1}$ & $\mathrm{~T}_{2}$ & $\mathrm{~T}_{3}$ & $\mathrm{~T}_{4}$ \\
\cline { 2 - 6 } Component & Fish meal & Yeast & Compounded feed & Hen egg yolk \\
\hline Moisture & 7.0 & 7.0 & 10.0 & 8.2 \\
Crude protein & 72.3 & 45.3 & 48.8 & 2.8 \\
Ether extract & 10.0 & 2.2 & 5.5 & 5.6 \\
Ash & 6.2 & 3.1 & 13.3 & 0.2 \\
Crude Fibre & 0.7 & 2.5 & 4.9 & 0 \\
\hline
\end{tabular}

Source: Field Survey 2010.

Table 4. Average values of water quality parameters monitored during the experiment

\begin{tabular}{|c|c|c|c|c|}
\hline & $\mathrm{T} 1$ & $\mathrm{~T} 2$ & $\mathrm{~T} 3$ & $\mathrm{~T} 4$ \\
\hline Parameters & Fish meal & Yeast & Compounded feed & Hen egg yolk \\
\hline Temperature $\left({ }^{\circ} \mathrm{C}\right)$ & 28 & 28 & 28 & 28 \\
\hline $\mathrm{pH}$ value & 7.2 & 7.2 & 7.2 & 7.2 \\
\hline $\mathrm{DO}_{2}(\mathrm{mg} / \mathrm{l})$ & 6.4 & 6.4 & 6.4 & 6.4 \\
\hline $\mathrm{NH}_{4}(\mathrm{mg} / \mathrm{l})$ & 0.5 & 0.5 & 0.5 & 0.5 \\
\hline $\mathrm{NO}_{2}(\mathrm{mg} / \mathrm{l})$ & 0.05 & 0.05 & 0.05 & 0.05 \\
\hline Turbidity (NYU) & 5.0 & 5.0 & 5.0 & 5.0 \\
\hline Total solids (mg/l) & 257 & 257 & 260 & 270 \\
\hline Acidity (mg/l) & 0.1 & 0.1 & 0.1 & 0.1 \\
\hline Total hardness (ppm) & 60 & 60 & 60 & 60 \\
\hline $\mathrm{Ca}^{2+}(\mathrm{ppm})$ & 42 & 43 & 50 & 40 \\
\hline $\mathrm{Mg}^{2+}(\mathrm{ppm})$ & 18 & 17 & 12 & 21 \\
\hline Chlorides (ppm) & 33 & 33 & 33 & 33 \\
\hline $\mathrm{Co}_{2} \quad$ Residual (ppm) & Nil & Nil & Nil & Nil \\
\hline Bacterial counts $/ 100 \mathrm{ml}$ & $\mathrm{TNC}$ & $\mathrm{TNC}$ & $\mathrm{TNC}$ & TNC \\
\hline Caliform counts (mpn) & Nil & Nil & Nil & Nil \\
\hline
\end{tabular}

Source: Field Survey 2010.

NB: Nil $=$ Zero and $\mathrm{TNC}=$ Too numerous to count 


\section{Discussion}

Fish meal (T1), Yeast (T2), Compounded feed (T3) and Hen egg yolk (T4) performance on the growth of the $C$. gariepinus larvae to fingerling was not significant $(\mathrm{P}>0.05)$. The specific growth rate $(\mathrm{P}>0.05)$ was not significant in all the treatments expect for $\mathrm{T} 3$. The food conversion efficiency by the fish was best in the treatment 4 (T4) with a value of 1.02, despite its low crude protein (CP) of $2.8 \%$, which was the lowest amongst all the treatments. This contradicts the report of ADCP (1993) which stated that the best growth rates and food conversion were achieved with diets containing 35-42\% crude protein and a calculated digestible energy level of 12kjg-1. Dupree and Huner (1984), reported that weight gain in fish is directly proportional to the protein content of the diet provided the levels of protein does not exceed $50 \%$. Cho et al., (1985) reported a $25 \%$ crude protein in diet as adequate for catfish fry rearing in order to obtain optimum growth in intensive culture.

The result of the percentage survival rates (range 1.7-10.0) recorded in this study was higher than that recorded by de Graaf et al. (1995) and Obuya et al. (1995). In South Africa, nursery ponds were repeatedly stocked at a rate of 2,000 fry $/ \mathrm{m}^{2}$ and about 500-800fingerlings $/ \mathrm{m}^{2}$ were harvested (Hecht et al., 1988).

"Madu et al., (2000) reported that the best survival (92\%) was recorded in the tanks sampled weekly, followed by bi-weekly sampling (84\%). The poorest survival $5.5 \%$ was obtained with the tanks sampled only once at harvest. Ironically, this treatment recorded the biggest sizes of fish (13.68 g mean weight) and one big "jumper" with a mean weight of $137.7 \mathrm{~g}$. This big "jumper" must have done a lot of damages to the smaller ones by cannibalizing on them so much as to reduce the survival to $5.5 \%$. The total weight of fish at harvest was best with the weekly and bi-weekly sampling interval followed by the tank sampled once. The least biomass or total weight of fish was recorded where no sampling took place until at harvest. They therefore recommended weekly sampling and bi-weekly sampling as the best sampling procedure for the outdoor nursery management of Clarias anguillaris fry and fingerlings".

The very high stocking density of $1,261 \mathrm{larvae} / \mathrm{m}^{2}$ carried out in this study grossly contradict the reports of the following authors on related studies; Kuronuma and Fukusho (1984) reported on sea bass rearing in tanks that the lower the initial density of larvae, the higher the survival rate. It was stated that the optimum stocking density for larval catfish was $100 / \mathrm{m}^{2}$, harvesting about 35-40fingerlings $/ \mathrm{m}^{2}$ after 5 weeks, with each fingerling weighing 2 - 3 $\mathrm{g}$ each (de Graaf et al., 1995). Increasing the initial stocking density did not increase the production, and lower stocking densities resulted in larger fingerlings being harvested. On the contrary, Campbell et al. (1995) stated that with higher stocking density more fingerlings per square meter were harvested.

Stocking density as high as 250 larvae $/ \mathrm{m}^{2}$ with an average production of 85 fingerlings $/ \mathrm{m}^{2}$ have only been obtained before in Africa by Janseen in Nigeria (unpublished data).

\section{Conclusion and Recommendations}

The poor survival rate of fingerlings recorded in this study could be as result of the intentional absence of sorting of "jumpers" throughout the study period which led to very high level of cannibalism and the outrageous stocking density of 1,261 larvae $/ \mathrm{m}^{2}$ which could be more likely responsible for the poor growth rate. Therefore, for further study on the use of dry feeds in catfish larval rearing it is recommended that lower stocking density and regular sorting of "jumpers" should be carried out to improve growth and survival rate, and cannibalism reduced to the bearest minimum.

\section{References}

ADCP Aquaculture Development and Coordination Programme. (1993). Fish feeds and feeding in developing countries. An interim report on the ADCP feed development programme. Rome, Italy. FAO-ADCP/REP/83/18:97.

Akinwande, A. A., Ugwumba, A. A. A., \& Ugwumba, O. A. (2002). Effects of replacement of fishmeal with maggot meal in the diet of Clarias gariepinus (Burchell, 1822) fingerlings: The Zoologist, 1(2), $41-46$.

Baruah, K., Sahu, N. P., \& Debnath, D. (2003). Dietary phytase: An ideal approach for a cost effective and low polluting aquafeed. $N A G A, 27(3), 15-19$.

Campbell, D. S., Obuya, \& Spoo, M. (1995). A simple method for small scale propagation of Clarias gariepinus in western Kenya, Field Document No. 2, FAO/TCP/KEN 4551, 27.

Cho, C. Y., Cowey, C. B., \& Watanabe, T. (1985). Protein requirement of catfish Fry, Pangesinssutch flower. In Fish Nutrition in Asia Development and Research Council Press, Ottawa Canada.

Dada, A. A., \& Akinwande, A. A. (2005). Growth performance of Heteroclarias fed maggot meal at varying inclusion levels. 2004 FISON Conference Proceedings, 896. 
de Graaf, G. J., Galemoni, F., \& Banzoussi, B. (1995). The artificial reproduction and fingerling production of the African catfish Clarias gariepinus (Burchell 1822) in protected and unprotected ponds. Aquaculture Research, 26, 233-242. http://dx.doi.org/10.1111/j.1365-2109.1995.tb00908.x

Delgado, C. L., Wada, N., Rosegrant, M. W., Meijer, S., \& Ahmed, M. (2003). Outlook for fish to 2020, Meeting Global Demand. pp. 28.

Duncan, D. B. (1955). Multiple Range and Multiple F-test Biometrics, 11(1), 1-42.

Eyo, A. A. (2004). Fundamentals of fish nutrition and diet development an overview. pp. 1-33. In A. A. Eyo (ed). National workshop on fish feed development and feeding practices in aquaculture NIFFRI, Newbussa 15th to 19th September, 2003. pp. 65.

Fagbenro, O. A. (1992). Utilization of Cocoa pud husk in low diets cost by Clarias isheriensis, (Syhenham). Aquaculture, 4, 175-182.

Falaye, A. E. (1988). Utilization of cocoa husk in the nutrition of tilapia (Oreochcromis niloticus). Ph.D. Thesis University of Ibadan, Nigeria. pp. 260.

Falaye, A. E. (1992). Utilization of agro-industrial wastes as fish feedstuffs in Nigeria. Proceedings of the 10th Annual Conference of FISON. pp. 47-57.

Hecht, O. I, \& Appelbaum, E. (1987). A Fish hatchery manual for Africa: a practical manual for producing seedstock of tilapia carp and catfish. Appendix I. pp. 183.

Kuronuma, K., \& Fukusho, K. (1984). Rearing of marine fish larvae in Japan. Ottawa, out., IDRC. p. 109.

Madu, C. T., Wonah, C., Issah, J., \& Okwuego, C. (2000). Effects of varying sampling intervals on growth and survival of Clarias anguillaris fry/fingerlings under outdoor nursery management. NIFFR 2000 Annual Report, NIFFR, New-Bussa, Nigeria.

Olatunde, A. A. (1996). Effect of supplementation of soyabean diet with L and D, L. methionine on the growth of mud fish Clarias anguillaris Nig. J. Biotech, 9(1), 9-16.

Olukunle, O. (2006). Nutritive potential of sweet potato peel meal and root replacement value for maize in diets of Africa catfish (Clarias gariepinus) advanced fry. J. Food Tech., 4(4), 289-293.

Omoruwou, P. E., \& Edema, C. U. (2011). Growth Response Of Heteroclarias Hybrid Fingerlings Fed On Maggot Based Diet. Nigerian Journal of Agriculture, Food and Environment, 7(1), 58-62.

Oso, J. A., Idowu, E. O., \& Agoi, O. F. (2011). Growth response of Clarias gariepinus fingerlings fed Parkia biglobosa diet as protein source. Indian Journal of Science and Technology, 4(2), 82-84.

Zhou, P., Zhang, W., Davis, D. A., \& Lim, C. (2010). Growth Response and Feed Utilization of Juvenile Hybrid Catfish Fed Diets Containing Distiller's Dried Grains with Solubles to Replace a Combination of Soybean Meal and Corn Meal. North American Journal of Aquaculture, 72, 298-303. http://dx.doi.org/10.1577/A10-002.1 